\title{
POLLEN MORPHOLOGY OF LYCIUM (SOLANACEAE) SPECIES IN IRAN
}

\author{
Fatemeh MOUSAVIMANESH, Maryam KESHAVARZI, Zahra NAZEM BOKAEE \\ Department of Plant Science, Faculty of Biological Sciences, Alzahra University, Tehran, Iran \\ e-mail: m.keshavarzi@alzahra.ac.ir \& neshat12000@yahoo.com
}

\begin{abstract}
Lycium (Solanaceae) has more than 100 species in arid and semi-arid parts of the world. In Iran, this medicinal plant is represented by 6 species, on which no palynological study has been conducted. Pollen morphology of 7 taxa are considered for the first time to evaluate the species relationships based on palynological data. Observations were made by use of Scanning electron microscopy on untreated pollen grains. Multivariate statistical analyses were carried out for qualitative and quantitative pollen features in the species studied. Results show that all pollen grains were monad, isopolar, zonotricolporate in prolate and preprolate shape. Exine sculpture was of striate and regulate patterns. Variations in pollen grains are considered to overcome the identification problems in species separation in morphologically similar taxa in this genus in Iran. The importance of pollen features in delimitation in some genera of Solanaceae was previously proven and the present study elucidates that some features as exine sculpture and some quantitative characters are of diagnostic importance in Lycium species native to Iran.
\end{abstract}

Keywords: exine, Lycium, Pollen grain, sculpture.

\section{Introduction}

Solanaceae, one of the most important families of flowering plants, provides economically important species such as the tomato, potato and other edible plants. Many species in this family are of economic and medicinal importance [9]. Lycium (Solanaceae, Solanoideae, Lycieae) comprises more than 100 species, which are distributed in arid and semi-arid habitats of the world. Lycium species are drought-resistant, rapidly growing thorny shrubs. This genus has 6 species in Iran: Lycium dasystemum Pojark, L. depressum Stocks (with 2 subspecies: L. depressum subsp. depressum Stocks and L. depressum Stocks subsp. angustifolium Schönb-Tem.), L. edgeworthii Dunal, L. kopetdaghi Pojrak, L. ruthenicum Murray and L. Shawii Roem. \& Schult. [1, 7, 12]. Lycium species are a subtropical element of North and South America, southern Africa, Eurasia and Australia [6]. It is believed that Lycium at first originated in the New World (South America) and then dispersed to Africa and Eurasia [2].

Pollen morphology of the Lycieae tribe, representing the 3 genera Lycium, Phrodus and Grabowskia, was studied by Bernardello \& Luján (1997). This tribe is recorded to be stenopalynous. The pollen grains are generally monad, 3-zonocolporate, oblate spheroidal or suboblate spheroidal. Colporus are long with a small polar region. The exine is semi-tectate with simple columella. The sculpture is striate and reticulate and in colporus the ornamentation is granular.

Perveen \& Qaiser (2007) studied the pollen grains of 20 species representing 7 genera of Solanaceae (including Lycium) from Pakistan by use of light and scanning electron microscope. 
They observed radially symmetrical, isopolar pollen grains with different shapes such as prolatespheroidal to oblate-spheroidal or sub-oblate to sub-prolate, tricolporate. Based on shape, apertures and exine sculpture they recognized 6 pollen types: Datura fastuosa-type, Lycium dasytemum type, Nicotiana plumbaginifolia-type, Physalis divaricata-type, Solanum nigrum-type and Withania somnifera-type. As there has been no palynological study of this genus in Iran, and Mousavimanesh (2016) stated the considerable morphological similarities between the species of this genus in Iran that complicate identification of the species, in the present study Lycium samples were gathered from different parts of Iran and the pollen morphology of taxa considered to evaluate the species relationships based on palynological data and to provide additional diagnostic features for species separation.

\section{Materials and Methods}

Pollen samples were obtained from field and herbarium specimens. The voucher details of 28 sampled populations are given in Table 1. Voucher specimens have been deposited in the Herbarium of Alzahra University (ALUH). Two samples were deposited in the Herbarium of Kerman University (MIR). Light microscopy observations were made with an Olympus DP12 microscope. Pollen morphology was based on 10-20 anthers from different specimens of each population.

For terminology of pollen grains and sexine sculpturing Punt et al. (2007) was followed. In order to study their surface features by Scanning Electron Microscopy (SEM), dry pollen grains were suspended in a drop of water and directly transferred to a metal stub using double-sided sellotape and coated with gold in a sputtering chamber (Sputter Coater BAL-TEC, SCDOOS). The coating was restricted to $100 \AA$. The SEM examination was carried out on TESCAN and Hitachi Scanning Electron Microscope. The measurements were based on 1-20 readings for each specimen. Pollen quantitative and qualitative features are set out in Table 2.

To reveal species relationships based on pollen grain data, cluster analysis and principal component analysis (PCA) were used. For multivariate analysis the mean of quantitative characters was used, while qualitative characters were coded as binary/multi-state characters. Standardized variables were used for multivariate statistical analysis. The average taxonomic distances and squared Euclidean distances were considered as a dissimilarity coefficient in cluster analysis of data. PAST software ver. $2.17 \mathrm{C}$ was used for statistical analysis.

\section{Results}

All pollen grains were in the form of monad and isopolar. Pollen grains were zonotricolporate (Figs $1 \& 2$ ). The longest polar axis was observed in L. depressum subsp. depressum (Fig. 1) while the shortest polar and equatorial axis were observed in L. edgeworthii (Fig. 2). Longest equatorial axis was found in L. kopetdaghi (Fig. 2) and the minimum length was observed in L. edgeworthii.

Pollen shape was of two types: prolate in L. dasystemum, L. depressum subsp. angustifolia, L. kopetdaghi and L. ruthenicum, and preprolate in L. depressum subsp. depressum, L. edgeworthii and L. shawii.

Exine sculpture was of the striate type except for L. shawii (Figs $1 \& 2$ ) with rugulate ornamentations. There was a fine sculpting in the form of perforations in L. kopetdaghi, L. 
ruthenicum and L. depressum subsp. depressum. The summary of observations is set out inTable 2 .

Table 1: Voucher details of Lycium species studied

\begin{tabular}{|c|c|c|}
\hline Taxon & Locality & Herbarium no. \\
\hline $\begin{array}{l}\text { Lycium depressum } \\
\text { subsp. depressum }\end{array}$ & $\begin{array}{l}\text { Khorassan, East of Torbat-e-Jam, near the } \\
\text { border of Afghanistan }\end{array}$ & MK34169ALUH \\
\hline L. depressum subsp. depressum & $\begin{array}{l}\text { Khorassan, East of Nehbandan, near the } \\
\text { border of Afghanistan }\end{array}$ & MK26484ALUH \\
\hline L. depressum subsp. depressum & $\begin{array}{l}\text { Khorassan, NE Rashtkhar, Garrmab } \\
\text { Fountain }\end{array}$ & MK23796ALUH \\
\hline L. depressum subsp. depressum & $\begin{array}{l}\text { Khorassan, Nehbandan, between Khan } \\
\text { Sharaf \& Tabasin }\end{array}$ & MK19802ALUH \\
\hline L. depressum subsp. depressum & Khorassan, Khaf, Bend-e-Salami & MK19191ALUH \\
\hline L. depressum subsp. depressum & Khorassan, E Ghayen, Hajiabad Dam. & MK34240ALUH \\
\hline L. depressum subsp. depressum & $\begin{array}{l}\text { Khorassan, Mashhad to Sarakhs, } \\
\text { Mazdavand }\end{array}$ & MK11961ALUH \\
\hline L. depressum subsp. depressum & Yazd, Yazd & MK7ALUH \\
\hline L. depressum subsp. angustifolium & $\begin{array}{l}\text { Khorassan, SE Torbat-e-Heydariyeh, } \\
\text { between Mahmoodabad and Jangal }\end{array}$ & MK14042ALUH \\
\hline L. depressum subsp. angustifolium & $\begin{array}{l}\text { Khorassan, E Rashtkhar, between Garmab } \\
\text { Fountain and Saadat Abad }\end{array}$ & MK23485ALUH \\
\hline L. depressum subsp. angustifolium & Kerman, Bardsir, Mahonak & MK12ALUH \\
\hline L. depressum subsp. angustifolium & Kerman, Bardsir, Negar & MK13ALUH \\
\hline L. depressum subsp. angustifolium & Kerman, Sirjan & MK14ALUH \\
\hline L. depressum subsp. angustifolium & Hormozgan, Bandar-e abbas, & $1191 \mathrm{MIR}$ \\
\hline L. ruthenicum & $\begin{array}{l}\text { Khorassan, S Sabzevar, between Hares } \\
\text { abad and Daulat abad }\end{array}$ & MK38881ALUH \\
\hline L. ruthenicum & Khorassan, Sarakhs, Yaz Tapeh & MK19442ALUH \\
\hline L. ruthenicum & Khorassan, Jajarm, W Amirabad & MK11347ALUH \\
\hline L. ruthenicum & Khorassan, E GHayen, Haji abad Dam & MK34244ALUH \\
\hline L. ruthenicum & Kerman, Kerman to Zarand, Chatroud & MK10ALUH \\
\hline L. ruthenicum & Sistan and Baluchistan, Zabol & MK16ALUH \\
\hline L. ruthenicum & Fars, Ghirokarzin & MK3ALUH \\
\hline L. ruthenicum & Qom, Jamkaran & MK5ALUH \\
\hline L. edgeworthii & $\begin{array}{l}\text { Hormozgan, between Bandar abbas and } \\
\text { Minab, Hasan Langi }\end{array}$ & MK15ALUH \\
\hline L. Shawii & Khuzestan, Ahvaz & MK1ALUH \\
\hline L. kopetdaghi & $\begin{array}{l}\text { Khorassan, NW Bojnourd, Between Sokhli } \\
\text { and Ayerghaye at Turkmenistan border }\end{array}$ & $\begin{array}{l}\text { MK33742 } \\
\text { ALUH }\end{array}$ \\
\hline L. kopetdaghi & $\begin{array}{l}\text { Khorassan, Daregaz, Tandoureh National } \\
\text { Park, Ali Bolagh }\end{array}$ & MK45284ALUH \\
\hline L. dasystemum & Kerman, Baft, Sange Laki & $1181 \mathrm{MIR}$ \\
\hline
\end{tabular}

In order to determine the most variable pollen characters among the Lycium species studied, factor analysis based on PCA was performed revealing that the first three factors comprise more than $94 \%$ of total observed variation. In the first factor with about $45 \%$ of total observed variation, characters as the presence or absence of perforation, colporus length, length of the polar axis and apocolporium possessed the highest positive correlation $(\geq 0.7)$. In the second factor with more than $30 \%$ of total observed variation, features as mesocolporium, width of colporous and 
shape of pollen at equatorial view possessed the highest positive correlations. These are the most variable features of pollen grains among the Lycium species of Iran.

Table 2: Summary of pollen morphology observations in Lycium species studied. (measurements in Micrometers)

\begin{tabular}{|c|c|c|c|c|c|c|c|}
\hline $\begin{array}{l}\text { Taxon / } \\
\text { Features }\end{array}$ & 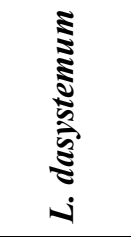 & 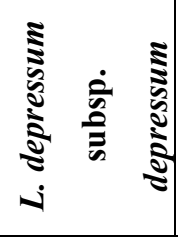 & 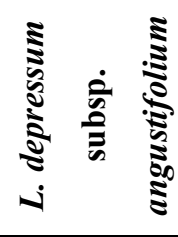 & 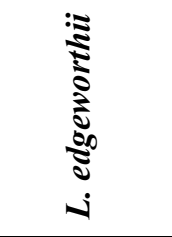 & 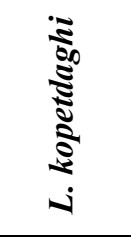 & $\frac{\sqrt{3}}{\sqrt[3]{5}}$ & 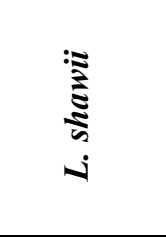 \\
\hline $\begin{array}{l}\text { Polar axis length } \\
(\mu \mathrm{m})\end{array}$ & $\begin{array}{c}29.05 \\
\pm 0.062\end{array}$ & $\begin{array}{l}42.49 \\
\pm 0.095\end{array}$ & $\begin{array}{c}40.1 \\
\pm 0.211\end{array}$ & $\begin{array}{c}26.61 \\
\pm 0.111\end{array}$ & $\begin{array}{c}41.13 \\
\pm 0.463\end{array}$ & $\begin{array}{l}41.34 \\
\pm 0.17\end{array}$ & $\begin{array}{c}30.19 \\
\pm 1.092\end{array}$ \\
\hline $\begin{array}{l}\text { Equatorial axis } \\
\text { length }(\mu \mathrm{m})\end{array}$ & $\begin{array}{c}13.96 \\
\pm 0.096\end{array}$ & $\begin{array}{c}21.71 \\
\pm 0.198\end{array}$ & $\begin{array}{c}19.94 \\
\pm 0.074\end{array}$ & $\begin{array}{c}13.21 \\
\pm 0.107\end{array}$ & $\begin{array}{c}22.03 \\
\pm 0.296\end{array}$ & $\begin{array}{c}18.57 \\
\pm 0.126\end{array}$ & $\begin{array}{l}16.79 \\
\pm 0.10\end{array}$ \\
\hline $\begin{array}{l}\text { Polar to } \\
\text { equatorial axis } \\
\text { ratio }\end{array}$ & 2.08 & 1.96 & 1.5 & 2.01 & 1.867 & 2.23 & 1.8 \\
\hline Colporus no. & 3 & 3 & 3 & 3 & 3 & 3 & 3 \\
\hline $\begin{array}{l}\text { Colporus length } \\
(\mu \mathrm{m})\end{array}$ & $\begin{array}{c}23.84 \\
\pm 0.396\end{array}$ & $\begin{array}{r}40.65 \\
\pm 0.967\end{array}$ & $\begin{array}{l}40.00 \\
\pm 2.59\end{array}$ & $\begin{array}{c}26.37 \\
\pm 1\end{array}$ & $\begin{array}{l}39.90 \\
\pm 1.14\end{array}$ & $\begin{array}{c}40.58 \\
\pm 0.298\end{array}$ & $\begin{array}{l}28.32 \\
\pm 0.11\end{array}$ \\
\hline $\begin{array}{l}\text { Colporus width } \\
(\mu \mathrm{m})\end{array}$ & $\begin{array}{c}1.989 \\
\pm 0.264\end{array}$ & $\begin{array}{c}1.966 \\
\pm 0.519\end{array}$ & $\begin{array}{c}3.156 \\
\pm 0.693\end{array}$ & $\begin{array}{c}3.156 \\
\pm 0.398\end{array}$ & $\begin{array}{c}2.495 \\
\pm 1.183\end{array}$ & $\begin{array}{l}3.098 \\
\pm 0.14\end{array}$ & $\begin{array}{l}1.270 \\
\pm 0.12\end{array}$ \\
\hline $\begin{array}{l}\text { Mesocolporium } \\
(\mu \mathrm{m})\end{array}$ & $\begin{array}{l}9.300 \\
\pm 0.04\end{array}$ & $\begin{array}{l}13.05 \\
\pm 0.0159\end{array}$ & $\begin{array}{l}19.8 \\
\pm 0.023\end{array}$ & $\begin{array}{l}16.4 \\
\pm 1.22\end{array}$ & $\begin{array}{c}14.11 \\
\pm 0.146\end{array}$ & $\begin{array}{c}12.83 \\
\pm 0.087\end{array}$ & $\begin{array}{c}16.4 \\
\pm 0.503\end{array}$ \\
\hline $\begin{array}{l}\text { Apocolporium } \\
(\mu \mathrm{m})\end{array}$ & $\begin{array}{c}3.83 \\
\pm 0.583\end{array}$ & $\begin{array}{c}5.74 \\
\pm 0.886\end{array}$ & $\begin{array}{c}2.50 \\
\pm 0.283\end{array}$ & $\begin{array}{c}3.64 \\
\pm 0.56\end{array}$ & $\begin{array}{l}4.08 \\
\pm 0.37\end{array}$ & $\begin{array}{c}4.21 \\
\pm 0.654\end{array}$ & $\begin{array}{c}3.64 \\
\pm 0.510\end{array}$ \\
\hline $\mathrm{Amb}$ & Circular & Circular & Circular & Circular & Circular & Circular & Circular \\
\hline $\begin{array}{l}\text { Pollen shape at } \\
\text { Equatorial view }\end{array}$ & Oblong & Oblong & Rhomboid & Oblong & Oblong & Oblong & Oblong \\
\hline Exine sculpture & Striate & Striate & Striate & Striate & Striate & Striate & Rugulate \\
\hline fine perforations & Absent & Present & Absent & Absent & Present & Present & Absent \\
\hline pollen shape & Prolate & Preprolate & Prolate & Preprolate & prolate & Prolate & Preprolate \\
\hline
\end{tabular}

Numerical methods were used to evaluate the species relationships. Cluster analysis based on pollen grain features revealed the accession relationships. Clustering pattern of dendrogram by WARD method shows two main clusters (Fig. 3). The first cluster comprises three species as $L$. depressum subsp. angustifolium, L. depressum subsp. depressum and L. kopetdaghi and $L$. ruthenicum. Other species are grouped in the second cluster. 


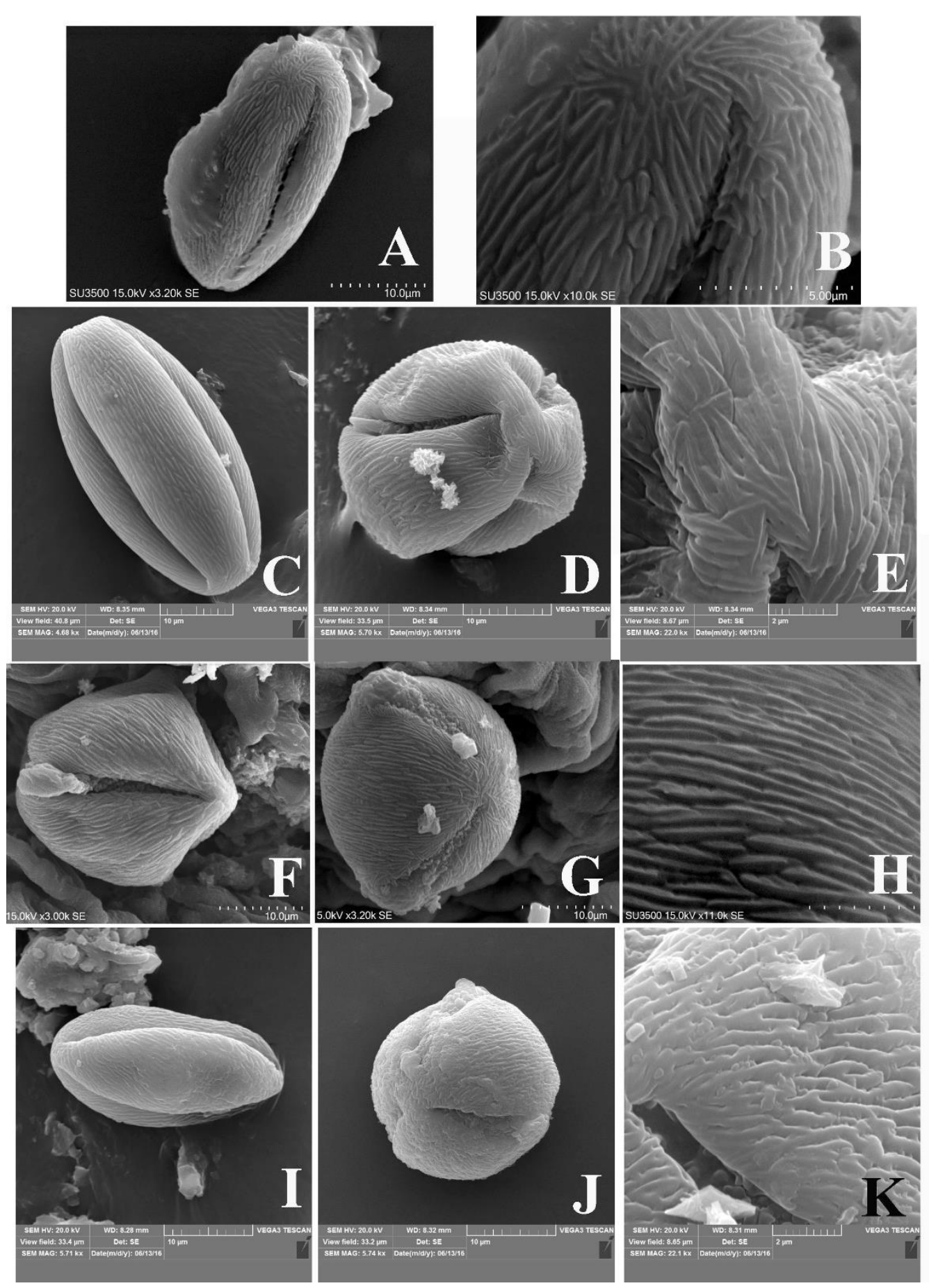

Fig. 1: Micrograph of pollen grains in: A \& B) Lycium dasystemum (A: polar view \& B: sculpture); C-E) L. depressum subsp. depressum; F-H) L. depressum subsp. angustifolium; I-K) L.edgeworthii (Equatorial view, polar view and sculpture respectively) 


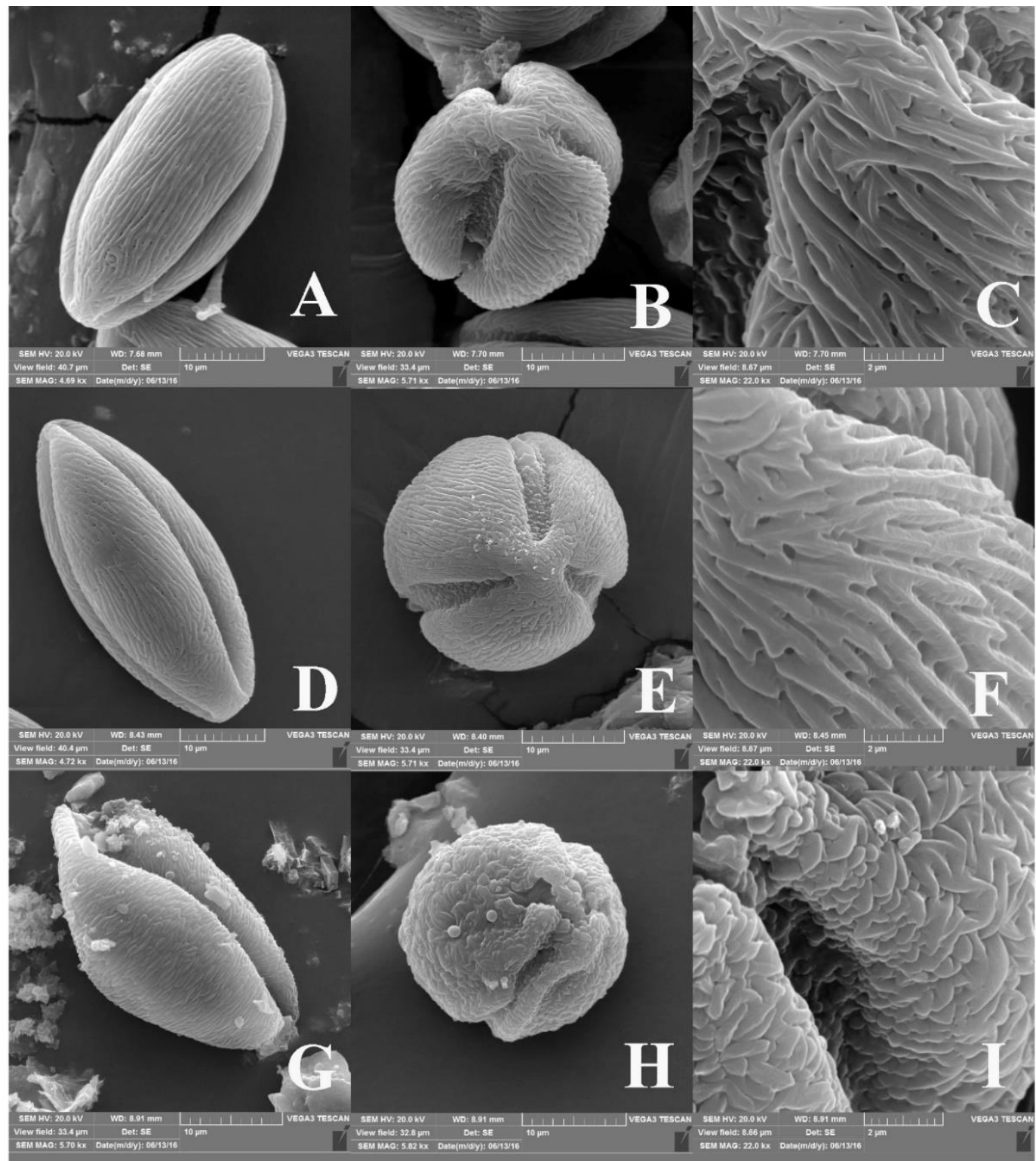

Fig. 2: Micrograph of pollen grains in: A -C) Lycium kopetdaghi; D-F) L. ruthenicum ; G-I) L. shawii (Equatorial view, polar view and sculpture respectively).

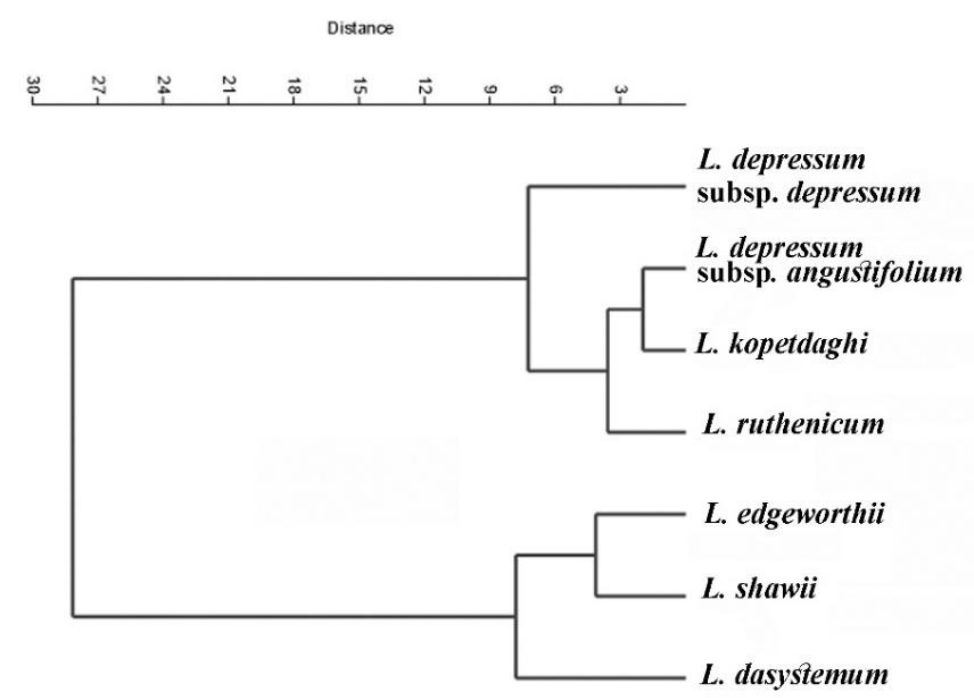

Fig. 3: WARD cluster of pollen grain features in Lycium species studies 
In the WARD dendrogram, L. Shawii and L. edgeworthii are grouped together. $L$. kopetdaghi show a close relationship with $L$. depressum subspecies.

\section{Discussion}

The taxonomic significance of pollen features in the Solanaceae family is rather uncertain. Sometimes different tribes or subtribes have a similar type of pollen, but genera of the same tribe or subtribe may have different types of pollen [5]. Solanaceae is identified by tricolporate and usually striate ornamentations in pollen grains. Song et al. (2018) stated that the general shapes of pollen grains in Solanaceae are mainly oblate spheroidal or prolate spheroidal, rarely being prolate, suboblate or subprolate. The shape of the pollen grains in Lycium varies from prolate to preprloate in Iranian elements, but there were reports of subprolate, prolate-spheroidal, oblate-spheroidal and suboblate grains too [4].

Perveen and Qaiser (2007) pointed to the triangular shape of Amb for L. dasystemum and L. depressum but all three studied taxa in present study show circular Amb. Despite Perveen and Qaiser (2007) who believed that L. ruthenicum has a scabrate type of ornamentation, in our observations, it has a striate exine sculpture pattern.

The striate ornamenatation is the main type of exine sculpture based on the literature [3]; here we find regulate in exine sculpture of L. shawii too.

Despite the taxonomic value of the pollen features in some Solanaceae genera as demonstrated by Erdtman (1952), Bernardello and Lujan (1997) have stated that pollen grain characters cannot efficiently separate genera in the tribe Lycieae and sections in the genus Lycium. Our findings about the species relationship, based on pollen grain features, is in agreement with the findings of Azadi Chegini et al. (2011), which showed by molecular study of chloroplast DNA that L. edgeworthii and L. shawii are closely related. They also indicated in their consensus tree that $L$. kopetdaghi is located near to L. depressum. This is in agreement with the pollen grouping found in the present study.

Finally, it should be mentioned that, despite a level of homogeneity and uniformity in the pollen features of species studied, selected quantitative characters and exine sculpture are of diagnostic value. Although there are some morphological differences between Lycium species studied [8], the micromorphological features could be used as an additional source of data in species delimitation.

Acknowledgement: Appreciation is expressed to Dr. Mansour Mirtajadini for his help in reviewing Lycium samples of the Kerman University (MIR) herbarium.

\section{REFERENCES}

1. Azadi, N., Nazeri, V., Shoushtari, A.N., Kazempour Osaloo, SH., 2007, Lycium dasystemum Pojark. (Solanaceae), a new record from Iran, Iranian Journal of Botany, 13 (2): 109-111.

2. Azadi Chegini, N., Nazeri, V., Shoushtari, A., Kazempour Osaloo, SH., 2011, Biogeography of Lycium L. (Solanaceae) and Phylogeny of Old-World Taxa Based on Sequences of nrDNA (ITS) and cpDNA (trnL-F), Iranian Journal of Biology, 24 (1):43-53 (In Persian).

3. Bernardello, L., Lujan, M.C., 1997, Pollen morphology of tribe Lycieae: Grabowskia, Lycium, Phrodus (Solanaceae), Review of palaeobotany and palynology, 96 (3): 305-315. 
4. Costa de Bringas, M.C., 1982, Contribución al conocimiento de la Flora Melífera de la Provincia de Córdoba. I, Departamento de Río Segundo, Boletin de la Sociedad Argentina de Botanica, 21 (1-4): 247-258.

5. Erdtman, G., 1952, Pollen Morphology and Plant Taxonomy. Angiosperms, Chronica Botanica Co., Waltham, Mass.

6. Fukuda, T., Yokoyama, J., Ohashi, H., 2001, Phylogeny and Biogeography of the Genus Lycium (Solanaceae): inferences from Chloroplast DNA Sequences, Molecular Phylogenetics and Evolution, 13: 246-258.

7. Khatamsaz, M., 1998, Solanaceae. In: Flora of Iran, no:24. Tehran (In Persian).

8. Mousavimanesh, F., 2016, Biosystematic study of the genus Lycium with emphasis on the morphology, pollen micromorphology and the variation in fatty acids profile in Iran, Masters thesis, Alzahra University.

9. Olmstead, R.G., Palmer, J.D., 1992,. A chloroplast DNA phylogeny of the Solanaceae: subfamilial relationships and character evolution, Annals of the Missouri Botanical Garden, 79 (2): 346-360.

10. Perveen, A., Qaiser, M., 2007, Pollen Morphology of Family Solanaceae from Pakistan, Pakistan journal of botany, 39 (7): 2243-2256.

11. Punt, W., Hoen, P.P., Blackmore, S., Nilsson, S., Le Thomas, A., 2007, Glossary of pollen and spore terminology, Review of Palaeobotany and Palynology, 143: 1-81.

12. Schonbeck-Temesy, E., 1972, Solanaceae. In: Rechinger, K.H., (ed.), Flora Iranica no: 100, Akademische Druck-u. Verlagsanstalt. Graz Austria.

13. Song, Y., Gu, L., Liu, J., 2018, Pollen morphology of selected species from the family Solanaceae, Palynology, $1-18$.

\section{MORFOLOGIA POLENULUI SPECIILOR DE LYCIUM (SOLANACEAE) DIN IRAN}

\section{(Rezumat)}

Genul Lycium (Solanaceae) cuprinde peste 100 de specii din zonele aride și semiaride ale lumii. În Iran, această plantă medicinală este reprezentată prin 6 specii, care nu au fost studiate din punct de vedere palinologic. Morfologia polenului la 7 taxoni este luată în considerare pentru prima dată pentru a evalua relațiile speciilor pe baza informațiilor palinologice. Observațiile au fost făcute cu ajutorul microsopului electronic de baleiaj asupra grăuncioarelor de polen netratate. S-au făcut analize statistice multivariate pentru a determina caracteristicile calitative și cantitative ale polenului la speciile luate în studiu. Rezultatele au arătat că toate grăuncioarele de polen sunt monade, izopolare, zonotricolporate și de formă alungită. Ornamentațiile exinei sunt striate sau cu model regulat. Pentru a identifica taxoni din Iran ai acestui gen, similari din punct de vedere morfologic, se apelează la studiul variabilității grăuncioarelor de polen. Importanța caracteristicilor polenului în identificarea unor genuri de Solanaceae a fost dovedită anterior, iar studiul prezent elucidează faptul că anumite caracteristici ale ornamentaţiilor exinei, precum și unele caracteristici cantitative au importanță pentru diagnoza speciilor de Lycium native din Iran.

Received: 7.01.2021; Accepted: 8.06.2021. 